\title{
Mental distress and psychological disorders of Syrians in fragile Syria and multiple countries related to COVID-19
}

\section{Ameer Kakaje ( $\sim$ ameer.kakaje@hotmail.com )}

Faculty of medicine, Damascus University, Damascus, Syria. https://orcid.org/0000-0002-3949-6109 Ammar Fadel

Faculty of medicine, Damascus University, Damascus, Syria.

\section{Ayham Ghareeb}

Faculty of medicine, Damascus University, Damascus, Syria.

\section{Ragheed Al Zohbi}

Faculty of medicine, Aleppo University, Aleppo, Syria

\section{Research Article}

Keywords: COVID-19, quarantine, refugees, Syria, psychological disorder, PTSD, mental disorder, global health

Posted Date: June 30th, 2020

DOl: https://doi.org/10.21203/rs.3.rs-39143/v1

License: (9) This work is licensed under a Creative Commons Attribution 4.0 International License. Read Full License

Version of Record: A version of this preprint was published at Global Mental Health on April 5th, 2021. See the published version at https://doi.org/10.1017/gmh.2021.12. 


\section{Abstract}

\section{Background:}

Syria has entered its ninth year of crisis which left millions of Syrians suffering from humanitarian crises. This study evaluates the mental health of Syrians living in Syria and who left the country due to war and living in different ten countries as evaluating their condition needs further study, particularly with Coronavirus disease of 2019 (COVID-19).

\section{Methods:}

Online questionnaires included SPTSS, K10, MSPSS, demographic, war- and COVID-19-related questions. This study included participants from 10 different countries and they were matched with Syrians according to age and gender as other variables could not be matched due to different standards between countries.

\section{Results:}

This study included 472 participants, of which 214 (45.3\%) were males with a mean age of $29.1 \pm 7.5$ ). More participants from Syria suffered from reduced ability to earn money $(P=0.007)$, and worried about being unable to provide food from COVID-19 $(P=0.007)$ although they worried less about them getting infected $(P=0.041)$.

Participants from Syria declared higher PTSD scores than Syrians living in other countries $(P=0.045)$, mainly among doctors. Interestingly, there was no significant difference in social support, days unable to work from distress in the past 4 weeks, and mental distress (K10) between Syrians living in Syria and other countries $(P>0.05)$.

\section{Conclusions:}

Syrians in Syria suffered more than Syrians living in other countries. Providing food and reduced ability to earn were the major stress. They also had more PTSD symptoms and stress than Syrians and others in other countries.

\section{Key Points}

- Syrian mental problems in Syria during COVID-19 were mostly from stress that their basic needs will be affected.

- No different in mental health disorders between Syrians living in different countries.

- PTSD prevalence in Syria was the highest, mainly among doctors. 
- COVID-19 mental burden among Syrians in different countries can resemble staying in Syria during war and basic needs being affected.

\section{Introduction}

Infections like Coronavirus disease of 2019 (COVID-19) can spread distress and cause symptoms of mental distress among populations (1). These manifestations should be made known so proper management can be taken place. COVID-19 has been declared an international emergency by the World Health Organisation (WHO) in January 2020. Syria has suffered nine years from war which left a high burden on psychological health as around half of the population suffered from either post-traumaticstress disorder and mental disorder, and more than two-thirds suffered from one or more of war variables either directly or indirectly (2). Similar problems were found in school students just before the full lockdown of Syria (3). As 11.1 million Syrian require humanitarian assistance in Syria, 5.5 million fled the country and around 6 million were internally displaced (2), a study that estimated the psychological burden on Syrians, especially in the COVID-19 crisis in different countries. This study is to estimate mental distress among Syrians, either living in Syria or not as there is no available data on the matter (4), particularly that Syria is considered a vulnerable country and number 4 worldwide in the most fragile countries, or very high alert in 2020 and was considered among the worsened countries in the past decade (5).

\section{Materials}

\section{1) Sampling:}

Online surveys were distributed in multiple groups, covering Syrians from different countries. Only Syrians were included, either living in Syria or had lived in Syria, but had to travel due to war regardless of the method and Visa status. No participants living in camps were included. This study was conducted in the period between $06 / 04 / 2020$ to $13 / 04 / 2019$. The questionnaires were posted online multiple times throughout the previous period at different times in online groups that were concerned with different topics. For each participant living outside Syria, a matching case was chosen randomly from participants who responded to the questionnaires. We only matched for age and gender as other variables will vary between countries such as the salary and SES. Scores were used rather than cut-off points in their study to add to the accuracy as it was an online-based survey not conducted by professionals or in a controlled centre.

\section{2) Consent and approval for study:}

Informed consent was taken before doing the survey. The informed consent was also taken for using and publishing the data. Confidentiality was assured by not asking or publishing any data that may referee to the individual identity. Our study did not include any participant under the age of 16 years.

Our study ethical aspect was approved by the Damascus University deanship in Damascus, Syria. 


\section{3) Questionnaires:}

\section{- PTSD:}

The Screen for Posttraumatic Stress Symptoms (SPTSS) tool was used for PTSD assessment. It is a screening tool based on the Diagnostic and Statistical Manual of Mental Disorders (DSM) IV. This tool contains avoidance, arousal, and re-experience clusters with five answers. The first two responses of "Not at all" and " 1 or 2 times" had a score of 0 while the other responses had the score 1 . It was considered positive when scoring for avoidance 3 or more, for arousal 2 or more, and for re-experience 1 or more. Although SPTSS was based on DSM-IV, not DSM-V which is the current version, it can be reliable, particularly it has a resemblance to the International Classification of Disease 11 (ICD-11) criteria.

\section{- Socioeconomic status (SES):}

It was assessed based on owning the house they live in, or it was rented, or living in friends' houses or it was given by the government. Due to differences between countries, monthly income was assessed based on being adequate for needs rather than numbers.

\section{- Social support:}

Multidimensional Scale of Perceived Social Support (MSPSS) $(6,7)$ was used. It is a self-reported scale to assess social support. MSPSS has 12 questions with each four questions assessing support from friends, significant other, or family.

\section{- Screening for mental disorder:}

Arabic Kessler 10 was used for psychological distress (8-10), which is a self-reported measure that has ten questions for anxiety and depression assessment in the previous four weeks. For the final scores, it ranges from 10 to 50 .

\section{- COVID-19 questions:}

We used translated questions from The CoRonavlruS Health Impact Survey (CRISIS) V0.1 Adult SelfReport Baseline Form (11) and are demonstrated in (Table 2).

\section{- Other Questions:}

Basic demographic questions were included (Table 1).

\section{- Definitions:}

IT work category involved any work that depended on computer science, IT, or communication engineering that required programming. The engineering work category involved civil, electrical, and mechanical engineering in addition to architecture. The retail worker was the type of job that required selling customer products, either in stores, online, or in person. Medical engineering was considered in 
"other health workers" category. Working in television, radio, show business, or journalism was categorised into "media" work type. "Office" work category involved working in a company office, or a private practice such as accounting and law. "Art and music" category involved working as a photographer, musician, painter, or designer except for a web designer.

Nearby countries category involved countries that surround Syria which are Lebanon, Jordan, Turkey, Iraq, and Iran.

\section{4) Data Process:}

Data were processed using IBM SPSS software version 26 for Windows (SPSS Inc, IL, USA). Chi-square, one-way analysis of variance (ANOVA), Binary regression, and independent t-tests were performed to determine statistical significance between the groups. Pearson correlation was also calculated. Values of less than 0.05 for the two-tailed $P$ values were considered statistically significant.

\section{Results}

This study included 472 participants, of which 214 (45.3\%) were males with a mean age of $29.1 \pm 7.5$. Participants from Syria were 236 (50\%), from Canada 13 (2.8\%), from Germany 57 (12.1\%), from Russia 11 (2.3\%), from the Gulf 49 (10.4\%), from Egypt 28 (5.9\%), and from nearby countries 78 (16.5\%). Characteristics of the sample, SES, and war variables are demonstrated in (Table 1). There was a statistical significant difference in the type of work between participants in Syria and outside of Syria $(P<0.001)$ which is demonstrated in (Figure 1). There were four participants under the age of 18 , two of them were 16, and the others were 17, with half of them living outside Syria.

\section{COVID-19 related variables:}

Comparisons of COVID-19 variables among Syrians in different countries are demonstrated in (Table 2). More participants from Syria suffered from reduced ability to earn money ( $P=0.007)$, and worried about being unable to provide food from COVID-19 (0.007) although they worried less about them getting infected $(P=0.041)$. However, there was no significant difference in the worries of family, friends, work, and studies being affected by COVID-19 ( $P>0.05)$. Participants in Syria also declared that their relationship with their friends or family deteriorated more than participants living in other countries $(P<0.05)$.

\section{Mental distress, PTSD, and social support related variables:}

Participants from Syria declared higher PTSD scores than Syrians living in other countries $(P=0.045)$. Interestingly, there was no statistically significant difference in social support, days unable to work from distress in the past 4 weeks and mental distress between Syrians living in Syria and other countries $(P>0.05)$. K10 scores, days unable to work, social support, and PTSD in different countries are demonstrated in (Table 3). 
When regressing total score PTSD, distress from being food affected, and distress that job being affected on living in Syria and not with using binary logistic regression, $P=0.012$ for $P T S D, P<0.001$ for distress food being affected, and $\mathrm{P}=0.021$ for distress that job being affected. When adding the adequacy of monthly income and living in a rented house or not, all $P$ values remained significant.

This study included 16 doctors from Syria and 16 outside Syria, and their K10 scores and SPTSS scores with other work categories according to inside or outside Syria are demonstrated in (Figure 2). Although Syrian doctors in Syria had higher SPTSS scores, they had no statistical difference in K10 scores.

\section{Discussion}

This study was conducted in a period where Syria was in its fourth week in total quarantine while it had less than ten cases of COVID-19 while other countries had their numbers rising rapidly. No major difference was found in mental distress before and after four weeks of quarantine among Syrians living in Syria (12). However, the distress was related more to worries from providing food and the reduced ability to work being affected. This study found that these concerns were more among Syrians living in Syria than outside. Moreover, high K-10 scores and SPTSS scores were correlated with more deterioration in relationships (12) which was found more commonly among Syrians living within Syria. With 11 million Syrian requiring humanitarians assistance and 8 out of 10 Syrians living in Syria are under the poverty line (13), it is rational to find providing food and reduced ability to earn were the major concerns in Syria causing major distress.

Interestingly, there was no difference in mental distress in the past 4 weeks among Syrians living inside or outside Syria which may indicate that the COVID-19 crisis has somewhat similar distress to the financial burden. However, PTSD burden was significantly higher either before the quarantine $(2,3)$, or after it (12) which suggests that the nine years of war had a significantly higher burden than COVID-19 direct effect at its peak in the world as Syria at that time had less than 10 cases of declared COVID-19. War has affected the medical sector throughout years of war as the direct damage of war to the medical centre and indirectly from physicians leaving the country (14). The financial hurdles also directly affected healthcare quality as proper tests and treatment may be delayed or not conducted despite having skilled physicians (15-17).

Overall, symptoms that suggest anxiety and depression were found to be around (16-28\%) and selfreported stress ( $8 \%$ ) in the literature (4) which was much less than what was found among Syrians inside or outside Syria according to this study and another one conducted in the same period (12). Quarantine was found to produce symptoms of anxiety, depression, acute panic, and PTSD, especially that COVID-19 had a stigma that can add even more to the burden (18). Doctors in Syria had higher PTSD symptoms which may reflect worse local conditions, particularly during COVID-19 despite not many confirmed cases at that time in Syria. New programs should aim to alleviate the high burden of Syrian society. New methods should be introduced to target Syrian populations as they do not have specific websites they refer to and they use standard search engines (19). 


\section{Limitations:}

We do recognise some of the limitations of our work; the number of participants should be larger, but due to the short time of data collection and the urgency of COVID-19, this was not achievable. This is an online study conducted on groups that limit the generality of the findings as the most affected individuals would not be reached. Many matching factors could not be implemented due to differences between countries' standards, particularly financially as salaries within Syria tend to be much less than in other countries. More details about war exposure and refugee status could not be detected as this would raise certain concerns, particularly for individuals living in Syria or planning to return. We received no funding which limited the tools and methods that could be used which was why we used self-reported assessment.

\section{Conclusion}

Syria has suffered from nine years of war which added to the suffering from COVID-19 and quarantine. Syrians in Syria in no doubt suffered much more than Syrians living in other countries. They particularly have concerns from providing food and reduced ability to earn. They also had more PTSD symptoms and stress than other countries and more than what COVID-19 caused among other countries, particularly doctors. However, Syrians had somewhat similar mental distress regardless of country of residency.

\section{Abbreviations}

\begin{tabular}{ll} 
ANOVA & Analysis of variance \\
\hline CI & Confidence Interval \\
\hline COVID-19 & Coronavirus disease of 2019. \\
\hline CRISIS & The CoRonavlruS Health Impact Survey \\
\hline DSM & Diagnostic and statistical manual of mental disorders \\
\hline ICD & International Classification of Disease \\
K10 & Kessler \\
\hline MSPSS & Multidimensional Scale of Perceived Social Support \\
\hline PTSD & post-traumatic stress disorder \\
\hline SES & Socioeconomic status \\
SPSS & Statistical Package for the Social Sciences \\
SPTSS & Screen for Posttraumatic Stress Symptoms \\
WHO & World Health Organisation
\end{tabular}




\section{Declarations}

\section{- Ethics approval and consent to participate:}

Online informed consent was taken before proceeding with the survey for participating in the research, and for using and publishing the data. We assured to maintain confidentiality and asked no questions that might reveal the person's identity. No subjects were under the age of 16 .

Our study protocol and ethical aspects were reviewed and approved by Damascus University deanship, Damascus, Syria.

\section{- Consent for publication:}

Online consent for using and publishing the data was taken before participating in the research.

\section{- Availability of data and materials:}

The data can be made available upon reasonable request.

- Competing interests:

We have no conflict of interest to declare.

- Funding:

No funding was received for this study

\section{- Authors' contributions:}

- AK: Conceptualization; Data curation; Formal analysis; Investigation; Methodology; Project administration; Supervision; Resources; Validation; original draft; Writing - review \& editing.

- AF: Review \& editing; original draft; Investigation; Software; Resources.

- AG: Conceptualization; Project administration; Editing; Software.

- RAZ: Project administration; Software; Investigation.

All authors have read and approved the manuscript.

\section{References}

1. Bao Y, Sun Y, Meng S, Shi J, Lu L. 2019-nCoV epidemic: address mental health care to empower society. The Lancet. 2020;395(10224):e37-e8.

2. Kakaje A, Zohbi RA, Aldeen OH, Makki L, Alyousbashi A, Alhaffar BA. Mental disorder and PTSD in Syria during wartime: a national-wide crisis. 2020. 
3. Kakaje A, Zohbi RA, Alyousbashi A, Abdelwahed RNK, Aldeen OH, Alhalabi MM, et al. Mental health of school students in Syria after nine years of conflict: a school-based study. 2020.

4. Rajkumar RP. COVID-19 and mental health: A review of the existing literature. Asian Journal of Psychiatry. 2020;52.

5. Peace TFo. Fragile States Index 202011 May 2020 [Available from: https://fundforpeace.org/2020/05/11/fragile-states-index-2020/.

6. Zimet G. Multidimensional Scale of Perceived Social Support (MSPSS) - Scale Items and Scoring Information. 2016.

7. R M, Kazarian S. Validation of the Arabic translation of the Multidensional Scale of Social Support (Arabic MSPSS) in a Lebanese community sample. Arab Journal of Psychiatry. 2012;23:159-68.

8. Andrews G, Slade T. Interpreting scores on the Kessler Psychological Distress Scale (K10). Australian and New Zealand Journal of Public Health. 2001;25(6):494-7.

9. Kessler RC, Andrews G, Colpe LJ, Hiripi E, Mroczek DK, Normand SLT, et al. Short screening scales to monitor population prevalences and trends in non-specific psychological distress. Psychological Medicine. 2002;32(6):959-76.

10. Palazón-Bru A, Sampasa-Kanyinga H, Zamorski MA, Colman I. The psychometric properties of the 10-item Kessler Psychological Distress Scale (K10) in Canadian military personnel. Plos One. 2018;13(4).

11. The CoRonavIruS Health Impact Survey (CRISIS) V0.3. Adult Self-Report Follow Up Form: Current Form: National Institute of Mental Health (NMIH); [Available from: https://www.nIm.nih.gov/dr2/CRISIS_Adult_Self-Report_Follow_Up_Current_Form_V0.3.pdf.

12. Kakaje A, Fadel A, Makki L, Ghareeb A, Zohbi RA. Mental distress and psychological disorders related to COVID-19 mandatory quarantine. 2020.

13. United Nations Office for the Coordination of Humanitarian Affairs (UNOCHA) (2020) Syria crisis overview [Available from: https://www.unocha.org/syrian-arab-republic/about-ocha-syria.

14. Saeed B. How Did the War Affect Organ Transplantation in Syria? Experimental and Clinical Transplantation. 2020;18(Suppl 1):19-21.

15. Ghareeb A, Kakaje A, Ghareeb A, Nahas MA. An enormous arteriovenous malformation presenting in a child in sacro-gluteal region and managed successfully by recurrent embolisation and surgery. International Journal of Surgery Case Reports. 2020.

16. Kakaje A, Awad R. Behcet's disease with primary hypothyroidism, adrenal insufficiency and coeliac disease: A case report. Clinical Case Reports. 2020.

17. Kakaje A, Mujahed R, Hamdan O, Hakim J. A large epithelioid angiomyolipoma of the kidney in a very young child with idiopathic chylothorax: A diagnostic dilemma. Urology Case Reports. 2020;28.

18. Dubey S, Biswas P, Ghosh R, Chatterjee S, Dubey MJ, Chatterjee S, et al. Psychosocial impact of COVID-19. Diabetes \& Metabolic Syndrome: Clinical Research \& Reviews. 2020;14(5):779-88. 
19. Alyousbashi A, Almahayni R. A cross-section study to assess Health Information Seeking Behavior (HISB) in Syria.

\section{Tables}


Table 1: Characteristics of the sample, SES, and war variables

\begin{tabular}{|c|c|c|c|c|c|c|c|c|c|c|}
\hline Characteristic & Syria & $\begin{array}{l}\text { Outside } \\
\text { Syria }\end{array}$ & $\begin{array}{c}P \\
\text { value }\end{array}$ & $\begin{array}{l}\text { Nearby } \\
\text { country }\end{array}$ & Canada & Egypt & UAE & Russia & Germany & $\begin{array}{c}\mathrm{P} \\
\text { value }\end{array}$ \\
\hline $\begin{array}{r}\text { Age: mean } \\
\text { (SD) }\end{array}$ & $\begin{array}{l}29.12 \\
(7.497)\end{array}$ & $\begin{array}{c}29.12 \\
(7.497)\end{array}$ & 1.000 & $\begin{array}{c}28.36 \\
(6.782)\end{array}$ & $\begin{array}{c}30.31 \\
(8.625)\end{array}$ & $\begin{array}{l}29.82 \\
(7.626)\end{array}$ & $\begin{array}{c}29.45 \\
(7.252)\end{array}$ & $\begin{array}{c}29.27 \\
(4.002)\end{array}$ & $\begin{array}{l}29.25 \\
(8.899)\end{array}$ & 0.961 \\
\hline $\begin{array}{l}\text { Gender } \\
\text { Male } \\
\text { Female }\end{array}$ & $\begin{array}{l}107 \\
129\end{array}$ & $\begin{array}{l}107 \\
129\end{array}$ & 1.000 & $\begin{array}{l}37 \\
41\end{array}$ & $\begin{array}{l}5 \\
8\end{array}$ & $\begin{array}{l}13 \\
15\end{array}$ & $\begin{array}{l}26 \\
23\end{array}$ & $\begin{array}{l}4 \\
7\end{array}$ & $\begin{array}{l}22 \\
35\end{array}$ & 0.811 \\
\hline $\begin{array}{l}\text { Change place of living due to war } \\
\text { No } \\
\text { Within the same city } \\
\text { To another city }\end{array}$ & $\begin{array}{l}139 \\
47 \\
47\end{array}$ & $\begin{array}{l}121 \\
14 \\
92\end{array}$ & $<0.001$ & $\begin{array}{c}36 \\
4 \\
35\end{array}$ & $\begin{array}{l}9 \\
0 \\
4\end{array}$ & $\begin{array}{c}10 \\
2 \\
15\end{array}$ & $\begin{array}{c}31 \\
4 \\
13\end{array}$ & $\begin{array}{l}7 \\
1 \\
1\end{array}$ & $\begin{array}{c}28 \\
3 \\
24\end{array}$ & $<0.001$ \\
\hline $\begin{array}{l}\text { Distress from war noises } \\
\text { No } \\
\text { Yes }\end{array}$ & $\begin{array}{c}38 \\
197\end{array}$ & $\begin{array}{r}46 \\
185\end{array}$ & 0.293 & $\begin{array}{l}15 \\
62\end{array}$ & $\begin{array}{l}7 \\
6\end{array}$ & $\begin{array}{c}3 \\
24\end{array}$ & $\begin{array}{c}9 \\
39\end{array}$ & $\begin{array}{r}0 \\
11\end{array}$ & $\begin{array}{l}12 \\
43\end{array}$ & 0.015 \\
\hline $\begin{array}{l}\text { Being a student } \\
\text { No } \\
\text { In a school } \\
\text { In a university of high institute }\end{array}$ & $\begin{array}{c}140 \\
3 \\
92\end{array}$ & $\begin{array}{l}168 \\
14 \\
53\end{array}$ & $<0.001$ & $\begin{array}{c}61 \\
0 \\
17\end{array}$ & $\begin{array}{l}6 \\
3 \\
4\end{array}$ & $\begin{array}{l}20 \\
0 \\
8\end{array}$ & $\begin{array}{l}43 \\
0 \\
6\end{array}$ & $\begin{array}{l}6 \\
0 \\
5\end{array}$ & $\begin{array}{l}32 \\
11 \\
13\end{array}$ & $<0.001$ \\
\hline $\begin{array}{l}\text { Education } \\
\text { Elementary } \\
\text { Until grade } 9 \\
\text { High School } \\
\text { University, or high institute } \\
\text { Master or higher }\end{array}$ & $\begin{array}{c}0 \\
10 \\
25 \\
164 \\
37\end{array}$ & $\begin{array}{c}1 \\
4 \\
45 \\
145 \\
41\end{array}$ & 0.031 & $\begin{array}{c}1 \\
3 \\
13 \\
47 \\
14\end{array}$ & $\begin{array}{l}0 \\
1 \\
3 \\
5 \\
4\end{array}$ & $\begin{array}{c}0 \\
0 \\
4 \\
24 \\
0\end{array}$ & $\begin{array}{c}0 \\
0 \\
8 \\
34 \\
7\end{array}$ & $\begin{array}{l}0 \\
0 \\
0 \\
6 \\
5\end{array}$ & $\begin{array}{c}0 \\
0 \\
17 \\
29 \\
11\end{array}$ & 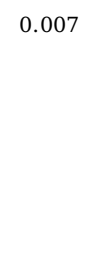 \\
\hline $\begin{array}{l}\text { House that you currently live in } \\
\text { Owned } \\
\text { Rented or given by the government } \\
\text { Living in friends\relatives house }\end{array}$ & $\begin{array}{c}132 \\
68 \\
36\end{array}$ & $\begin{array}{c}30 \\
188 \\
17\end{array}$ & $<0.001$ & $\begin{array}{c}10 \\
62 \\
6\end{array}$ & $\begin{array}{c}3 \\
10 \\
0\end{array}$ & $\begin{array}{c}3 \\
22 \\
3\end{array}$ & $\begin{array}{c}5 \\
39 \\
5\end{array}$ & $\begin{array}{l}2 \\
8 \\
1\end{array}$ & $\begin{array}{c}7 \\
47 \\
2\end{array}$ & $<0.001$ \\
\hline $\begin{array}{l}\text { Marital Status } \\
\text { Single } \\
\text { In a relationship } \\
\text { Married } \\
\text { Divorced } \\
\text { Engaged } \\
\text { Widowed }\end{array}$ & $\begin{array}{c}119 \\
19 \\
72 \\
3 \\
16 \\
5\end{array}$ & $\begin{array}{c}82 \\
15 \\
112 \\
11 \\
13 \\
2\end{array}$ & $<0.001$ & $\begin{array}{c}29 \\
1 \\
36 \\
5 \\
6 \\
1\end{array}$ & $\begin{array}{l}7 \\
2 \\
3 \\
1 \\
0 \\
0\end{array}$ & $\begin{array}{c}11 \\
4 \\
10 \\
2 \\
1 \\
0\end{array}$ & $\begin{array}{c}19 \\
3 \\
22 \\
1 \\
3 \\
1\end{array}$ & $\begin{array}{l}2 \\
1 \\
8 \\
0 \\
0 \\
0\end{array}$ & $\begin{array}{c}14 \\
4 \\
33 \\
2 \\
3 \\
0\end{array}$ & 0.030 \\
\hline $\begin{array}{l}\text { Smoking cigarette or shisha } \\
\text { I was not a smoker and did not start } \\
\text { I used to smoke one of them but now I } \\
\text { smoke both } \\
\text { Yes I am smoking now and before } \\
\text { COVID } 19 \\
\text { I started smoking cigarettes } \\
\text { I started Shisha }\end{array}$ & $\begin{array}{c}139 \\
4 \\
83 \\
3 \\
2\end{array}$ & $\begin{array}{c}138 \\
4 \\
80 \\
4 \\
4\end{array}$ & 0.929 & $\begin{array}{c}42 \\
1 \\
32 \\
0 \\
2\end{array}$ & $\begin{array}{l}7 \\
1 \\
2 \\
1 \\
0\end{array}$ & $\begin{array}{c}20 \\
0 \\
7 \\
0 \\
0\end{array}$ & $\begin{array}{c}28 \\
1 \\
18 \\
2 \\
0\end{array}$ & $\begin{array}{l}8 \\
0 \\
3 \\
0 \\
0\end{array}$ & $\begin{array}{c}33 \\
1 \\
18 \\
1 \\
2\end{array}$ & 0.598 \\
\hline $\begin{array}{l}\text { SmokingChangesFrom COVID19 } \\
\text { Stopped smoking } \\
\text { Almost the same } \\
\text { Increased dramatically } \\
\text { Decreased dramatically }\end{array}$ & $\begin{array}{r}2 \\
17 \\
15 \\
31\end{array}$ & $\begin{array}{r}2 \\
31 \\
23 \\
17\end{array}$ & 0.024 & $\begin{array}{c}1 \\
13 \\
10 \\
6\end{array}$ & $\begin{array}{l}0 \\
2 \\
2 \\
0\end{array}$ & $\begin{array}{l}1 \\
2 \\
1 \\
2\end{array}$ & $\begin{array}{l}0 \\
5 \\
3 \\
6\end{array}$ & $\begin{array}{l}0 \\
1 \\
2 \\
0\end{array}$ & $\begin{array}{l}0 \\
8 \\
5 \\
3\end{array}$ & 0.278 \\
\hline $\begin{array}{l}\text { Monthly Income adequacy } \\
\text { It cannot cover buying the essentials }\end{array}$ & $\begin{array}{r}58 \\
144\end{array}$ & $\begin{array}{r}27 \\
115\end{array}$ & $<0.001$ & $\begin{array}{l}14 \\
42\end{array}$ & $\begin{array}{l}1 \\
3\end{array}$ & $\begin{array}{r}5 \\
11\end{array}$ & $\begin{array}{c}6 \\
24\end{array}$ & $\begin{array}{l}1 \\
5\end{array}$ & $\begin{array}{l}0 \\
30\end{array}$ & $<0.001$ \\
\hline
\end{tabular}




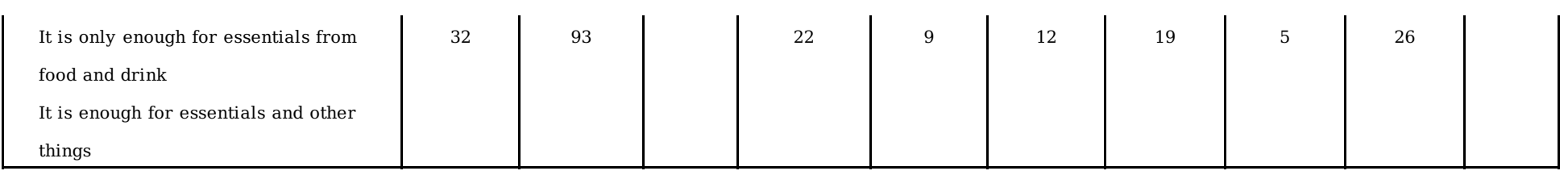

Page 12/18 
Table 2: Comparisons of COVID-19 variables among Syrians in different countries.

\begin{tabular}{|c|c|c|c|c|c|c|c|c|c|c|}
\hline Characteristic & Syria & $\begin{array}{c}\text { Outside } \\
\text { Syria }\end{array}$ & $\begin{array}{c}P \\
\text { value }\end{array}$ & $\begin{array}{l}\text { Nearby } \\
\text { country }\end{array}$ & Canada & Egypt & UAE & Russia & Germany & $\begin{array}{c}P \\
\text { value }\end{array}$ \\
\hline $\begin{array}{l}\text { Have you been suspected of having COVID-19 } \\
\text { No symptoms or signs } \\
\text { Yes, has some possible symptoms, but no diagnosis } \\
\text { Yes, I was diagnosed with COVID-19 by a doctor }\end{array}$ & $\begin{array}{c}232 \\
3 \\
0\end{array}$ & $\begin{array}{c}218 \\
13 \\
0\end{array}$ & 0.010 & $\begin{array}{l}75 \\
2 \\
0\end{array}$ & $\begin{array}{l}12 \\
1 \\
0\end{array}$ & $\begin{array}{l}26 \\
2 \\
0\end{array}$ & $\begin{array}{c}44 \\
4 \\
0\end{array}$ & $\begin{array}{l}9 \\
1 \\
0\end{array}$ & $\begin{array}{c}52 \\
3 \\
0\end{array}$ & 0.095 \\
\hline $\begin{array}{l}\text { Exposed to someone likely to have COVID-19 } \\
\text { No } \\
\text { Yes, has some possible symptoms, but no diagnosis by } \\
\text { doctor } \\
\text { Yes, with someone was diagnosed by a doctor }\end{array}$ & $\begin{array}{l}219 \\
12\end{array}$ & $\begin{array}{l}212 \\
16 \\
4\end{array}$ & 0.289 & $\begin{array}{l}74 \\
3 \\
1\end{array}$ & $\begin{array}{l}12 \\
1\end{array}$ & $\begin{array}{c}26 \\
2\end{array}$ & $\begin{array}{l}45 \\
2 \\
1\end{array}$ & $\begin{array}{c}10 \\
0\end{array}$ & $\begin{array}{l}45 \\
8 \\
2\end{array}$ & 0.261 \\
\hline $\begin{array}{l}\text { Anyone in your family been diagnosed with COVID-19 } \\
\text { No } \\
\text { Yes, non-household member } \\
\text { Yes, member of household }\end{array}$ & $\begin{array}{c}232 \\
1 \\
2\end{array}$ & $\begin{array}{c}227 \\
2 \\
6\end{array}$ & 0.303 & $\begin{array}{l}77 \\
1 \\
0\end{array}$ & $\begin{array}{l}11 \\
1 \\
1\end{array}$ & $\begin{array}{c}28 \\
0 \\
0\end{array}$ & $\begin{array}{l}49 \\
0 \\
0\end{array}$ & $\begin{array}{l}11 \\
0 \\
0\end{array}$ & $\begin{array}{l}51 \\
0 \\
5\end{array}$ & $<0.001$ \\
\hline $\begin{array}{l}\text { Happened because of COVID-19: } \\
\text { Fallen ill physically } \\
\text { No } \\
\text { To a family member } \\
\text { To a housemate } \\
\text { To you }\end{array}$ & $\begin{array}{c}208 \\
18 \\
1 \\
8\end{array}$ & $\begin{array}{c}204 \\
15 \\
4 \\
12\end{array}$ & 0.405 & $\begin{array}{l}70 \\
2 \\
1 \\
5\end{array}$ & $\begin{array}{l}13 \\
0 \\
0 \\
0\end{array}$ & $\begin{array}{l}24 \\
2 \\
1 \\
1\end{array}$ & $\begin{array}{l}41 \\
5 \\
1 \\
2\end{array}$ & $\begin{array}{l}11 \\
0 \\
0 \\
0\end{array}$ & $\begin{array}{l}45 \\
6 \\
1 \\
4\end{array}$ & 0.748 \\
\hline $\begin{array}{l}\text { Hospitalised } \\
\text { No } \\
\text { To a family member } \\
\text { To a housemate } \\
\text { To you }\end{array}$ & $\begin{array}{c}228 \\
5 \\
1 \\
1\end{array}$ & $\begin{array}{c}231 \\
4 \\
0 \\
0\end{array}$ & 0.546 & $\begin{array}{l}78 \\
0 \\
0 \\
0\end{array}$ & $\begin{array}{l}13 \\
0 \\
0 \\
0\end{array}$ & $\begin{array}{l}27 \\
1 \\
0 \\
0\end{array}$ & $\begin{array}{l}46 \\
3 \\
0 \\
0\end{array}$ & $\begin{array}{l}11 \\
0 \\
0 \\
0\end{array}$ & $\begin{array}{l}56 \\
0 \\
0 \\
0\end{array}$ & 0.926 \\
\hline $\begin{array}{l}\text { Self-quarantine with symptoms } \\
\text { No } \\
\text { To a family member } \\
\text { To a housemate } \\
\text { To you }\end{array}$ & $\begin{array}{c}233 \\
0 \\
2 \\
0\end{array}$ & $\begin{array}{c}233 \\
1 \\
0 \\
1\end{array}$ & 0.261 & $\begin{array}{l}78 \\
0 \\
0 \\
0\end{array}$ & $\begin{array}{l}12 \\
1 \\
0 \\
0\end{array}$ & $\begin{array}{l}28 \\
0 \\
0 \\
0\end{array}$ & $\begin{array}{l}48 \\
0 \\
0 \\
1\end{array}$ & $\begin{array}{l}11 \\
0 \\
0 \\
0\end{array}$ & $\begin{array}{l}56 \\
0 \\
0 \\
0\end{array}$ & $<0.001$ \\
\hline $\begin{array}{l}\text { Self-quarantine without symptoms } \\
\text { No } \\
\text { To a family member } \\
\text { To a housemate } \\
\text { To you }\end{array}$ & $\begin{array}{c}232 \\
1 \\
2 \\
0\end{array}$ & $\begin{array}{c}227 \\
1 \\
2 \\
5\end{array}$ & 0.168 & $\begin{array}{l}75 \\
0 \\
0 \\
3\end{array}$ & $\begin{array}{l}13 \\
0 \\
0 \\
0\end{array}$ & $\begin{array}{l}28 \\
0 \\
0 \\
0\end{array}$ & $\begin{array}{l}46 \\
0 \\
2 \\
1\end{array}$ & $\begin{array}{l}10 \\
1 \\
0 \\
0\end{array}$ & $\begin{array}{c}55 \\
0 \\
0 \\
1\end{array}$ & 0.004 \\
\hline $\begin{array}{l}\text { Lost Job } \\
\text { No } \\
\text { To a family member } \\
\text { To a housemate } \\
\text { To you } \\
\text { Two of the previous } \\
\text { All of the previouse }\end{array}$ & $\begin{array}{c}162 \\
31 \\
3 \\
15 \\
17 \\
5\end{array}$ & $\begin{array}{c}168 \\
27 \\
9 \\
13 \\
6 \\
8\end{array}$ & 0.092 & $\begin{array}{l}51 \\
12 \\
4 \\
1 \\
3 \\
4\end{array}$ & $\begin{array}{l}8 \\
2 \\
1 \\
1 \\
0 \\
0\end{array}$ & $\begin{array}{l}25 \\
0 \\
1 \\
2 \\
0 \\
0\end{array}$ & $\begin{array}{l}37 \\
3 \\
1 \\
4 \\
2 \\
2\end{array}$ & $\begin{array}{l}8 \\
3 \\
0 \\
0 \\
0 \\
0\end{array}$ & $\begin{array}{l}39 \\
7 \\
2 \\
5 \\
1 \\
2\end{array}$ & 0.428 \\
\hline $\begin{array}{l}\text { Reduced ability to earn money } \\
\text { No } \\
\text { To a family member } \\
\text { To a housemate } \\
\text { To you } \\
\text { Two of the previous } \\
\text { All of the previous }\end{array}$ & $\begin{array}{c}138 \\
46 \\
4 \\
13 \\
24 \\
8\end{array}$ & $\begin{array}{c}155 \\
28 \\
9 \\
23 \\
10 \\
7\end{array}$ & 0.007 & $\begin{array}{l}7 \\
2 \\
1 \\
3 \\
0 \\
0\end{array}$ & $\begin{array}{c}40 \\
12 \\
5 \\
6 \\
8 \\
5\end{array}$ & $\begin{array}{l}21 \\
3 \\
1 \\
3 \\
0 \\
0\end{array}$ & $\begin{array}{l}34 \\
5 \\
1 \\
7 \\
0 \\
1\end{array}$ & $\begin{array}{l}8 \\
2 \\
1 \\
0 \\
0 \\
0\end{array}$ & $\begin{array}{l}45 \\
4 \\
0 \\
4 \\
2 \\
1\end{array}$ & 0.019 \\
\hline Passed away & 232 & 233 & 0.606 & 13 & 78 & 28 & 47 & 11 & 56 & 0.732 \\
\hline
\end{tabular}

Page 13/18 


\begin{tabular}{|c|c|c|c|c|c|c|c|c|c|c|}
\hline $\begin{array}{l}\text { No } \\
\text { To a family member } \\
\text { To a housemate }\end{array}$ & $\begin{array}{l}2 \\
1\end{array}$ & $\begin{array}{l}2 \\
0\end{array}$ & & $\begin{array}{l}0 \\
0\end{array}$ & $\begin{array}{l}0 \\
0\end{array}$ & $\begin{array}{l}0 \\
0\end{array}$ & $\begin{array}{l}2 \\
0\end{array}$ & $\begin{array}{l}0 \\
0\end{array}$ & $\begin{array}{l}0 \\
0\end{array}$ & \\
\hline $\begin{array}{l}\text { How worried have you been from: } \\
\text { Being infected } \\
\text { Not at all } \\
\text { Slightly } \\
\text { Moderately } \\
\text { Very }\end{array}$ & $\begin{array}{l}69 \\
82 \\
49 \\
28\end{array}$ & $\begin{array}{c}43 \\
101 \\
52 \\
31\end{array}$ & 0.041 & $\begin{array}{l}3 \\
4 \\
3 \\
3\end{array}$ & $\begin{array}{c}13 \\
36 \\
17 \\
8\end{array}$ & $\begin{array}{c}5 \\
10 \\
9 \\
2\end{array}$ & $\begin{array}{c}10 \\
19 \\
9 \\
9\end{array}$ & $\begin{array}{l}0 \\
6 \\
3 \\
2\end{array}$ & $\begin{array}{c}12 \\
26 \\
11 \\
7\end{array}$ & 0.483 \\
\hline $\begin{array}{l}\text { Friends or family being infected } \\
\text { Not at all } \\
\text { Slightly } \\
\text { Moderately } \\
\text { Very }\end{array}$ & $\begin{array}{l}20 \\
58 \\
70 \\
76\end{array}$ & $\begin{array}{l}14 \\
53 \\
63 \\
92\end{array}$ & 0.367 & $\begin{array}{l}2 \\
4 \\
1 \\
5\end{array}$ & $\begin{array}{c}4 \\
19 \\
26 \\
24\end{array}$ & $\begin{array}{c}2 \\
5 \\
7 \\
11\end{array}$ & $\begin{array}{c}3 \\
9 \\
9 \\
26\end{array}$ & $\begin{array}{l}0 \\
4 \\
1 \\
6\end{array}$ & $\begin{array}{c}3 \\
12 \\
19 \\
20\end{array}$ & 0.415 \\
\hline $\begin{array}{l}\text { Your work will be negatively affected } \\
\text { Not at all } \\
\text { Slightly } \\
\text { Moderately } \\
\text { Very }\end{array}$ & $\begin{array}{l}79 \\
36 \\
35 \\
59\end{array}$ & $\begin{array}{l}68 \\
38 \\
35 \\
66\end{array}$ & 0.739 & $\begin{array}{l}5 \\
1 \\
0 \\
6\end{array}$ & $\begin{array}{c}24 \\
10 \\
9 \\
31\end{array}$ & $\begin{array}{c}12 \\
3 \\
5 \\
5\end{array}$ & $\begin{array}{c}12 \\
6 \\
11 \\
11\end{array}$ & $\begin{array}{l}3 \\
0 \\
1 \\
5\end{array}$ & $\begin{array}{c}12 \\
18 \\
9 \\
8\end{array}$ & 0.009 \\
\hline $\begin{array}{l}\text { Your studies will be negatively affected } \\
\text { Not at all } \\
\text { Slightly } \\
\text { Moderately } \\
\text { Very }\end{array}$ & $\begin{array}{c}103 \\
20 \\
32 \\
40\end{array}$ & $\begin{array}{l}87 \\
18 \\
24 \\
34\end{array}$ & 0.974 & $\begin{array}{l}4 \\
1 \\
2 \\
5\end{array}$ & $\begin{array}{c}33 \\
6 \\
2 \\
11\end{array}$ & $\begin{array}{l}10 \\
1 \\
2 \\
4\end{array}$ & $\begin{array}{c}20 \\
3 \\
4 \\
5\end{array}$ & $\begin{array}{l}2 \\
1 \\
3 \\
2\end{array}$ & $\begin{array}{c}18 \\
6 \\
11 \\
7\end{array}$ & 0.355 \\
\hline $\begin{array}{l}\text { Providing food will be affected } \\
\text { Not at all } \\
\text { Slightly } \\
\text { Moderately } \\
\text { Very }\end{array}$ & $\begin{array}{l}52 \\
62 \\
44 \\
62\end{array}$ & $\begin{array}{l}84 \\
51 \\
38 \\
44\end{array}$ & 0.007 & $\begin{array}{l}5 \\
2 \\
2 \\
3\end{array}$ & $\begin{array}{l}23 \\
17 \\
15 \\
20\end{array}$ & $\begin{array}{l}4 \\
8 \\
5 \\
8\end{array}$ & $\begin{array}{c}18 \\
10 \\
8 \\
8\end{array}$ & $\begin{array}{l}2 \\
5 \\
2 \\
1\end{array}$ & $\begin{array}{c}32 \\
9 \\
6 \\
4\end{array}$ & 0.002 \\
\hline $\begin{array}{l}\text { Are you committed to quarantine } \\
\text { I do not go out at all } \\
\text { Only for essentials } \\
\text { Reduced my going out } \\
\text { Have not changed at all } \\
\end{array}$ & $\begin{array}{c}44 \\
160 \\
25 \\
6\end{array}$ & $\begin{array}{c}58 \\
152 \\
20 \\
4\end{array}$ & 0.379 & $\begin{array}{l}1 \\
9 \\
3 \\
0\end{array}$ & $\begin{array}{c}23 \\
49 \\
6 \\
0\end{array}$ & $\begin{array}{c}8 \\
17 \\
2 \\
1\end{array}$ & $\begin{array}{c}12 \\
31 \\
3 \\
2\end{array}$ & $\begin{array}{l}4 \\
4 \\
3 \\
0\end{array}$ & $\begin{array}{c}10 \\
42 \\
3 \\
1\end{array}$ & 0.272 \\
\hline $\begin{array}{l}\text { Quality of your relationships with your friends } \\
\text { A lot better } \\
\text { A little better } \\
\text { About the same } \\
\text { A little worse } \\
\text { A lot worse }\end{array}$ & $\begin{array}{c}1 \\
20 \\
160 \\
33 \\
20\end{array}$ & $\begin{array}{c}3 \\
24 \\
170 \\
27 \\
6\end{array}$ & 0.044 & $\begin{array}{c}0 \\
3 \\
10 \\
0 \\
0\end{array}$ & $\begin{array}{c}3 \\
8 \\
54 \\
9 \\
3\end{array}$ & $\begin{array}{c}0 \\
1 \\
23 \\
2 \\
1\end{array}$ & $\begin{array}{c}0 \\
6 \\
33 \\
7 \\
1\end{array}$ & $\begin{array}{l}0 \\
0 \\
9 \\
1 \\
1\end{array}$ & $\begin{array}{c}0 \\
6 \\
41 \\
8 \\
0\end{array}$ & 0.215 \\
\hline $\begin{array}{l}\text { Quality of your relationships with your housemates } \\
\text { A lot better } \\
\text { A little better } \\
\text { About the same } \\
\text { A little worse } \\
\text { A lot worse }\end{array}$ & $\begin{array}{c}11 \\
55 \\
133 \\
30 \\
4\end{array}$ & $\begin{array}{c}14 \\
42 \\
123 \\
37 \\
5\end{array}$ & 0.554 & $\begin{array}{c}1 \\
2 \\
10 \\
0 \\
0\end{array}$ & $\begin{array}{c}5 \\
17 \\
42 \\
9 \\
0\end{array}$ & $\begin{array}{c}2 \\
3 \\
13 \\
8 \\
0\end{array}$ & $\begin{array}{c}1 \\
9 \\
21 \\
11 \\
3\end{array}$ & $\begin{array}{l}1 \\
2 \\
8 \\
0 \\
0\end{array}$ & $\begin{array}{c}4 \\
9 \\
29 \\
9 \\
2\end{array}$ & 0.268 \\
\hline $\begin{array}{l}\text { Quality of the relationships between you and members of } \\
\text { your family } \\
\text { A lot better } \\
\text { A little better } \\
\text { About the same } \\
\text { A little worse } \\
\text { A lot worse }\end{array}$ & $\begin{array}{c}4 \\
32 \\
152 \\
29 \\
13\end{array}$ & $\begin{array}{c}9 \\
34 \\
159 \\
15 \\
5\end{array}$ & 0.040 & $\begin{array}{c}1 \\
2 \\
10 \\
0 \\
0\end{array}$ & $\begin{array}{c}4 \\
11 \\
55 \\
6 \\
1\end{array}$ & $\begin{array}{c}0 \\
3 \\
19 \\
4 \\
0\end{array}$ & $\begin{array}{c}2 \\
10 \\
28 \\
2 \\
2\end{array}$ & $\begin{array}{l}0 \\
2 \\
9 \\
0 \\
0\end{array}$ & $\begin{array}{c}2 \\
6 \\
38 \\
3 \\
2\end{array}$ & 0.610 \\
\hline
\end{tabular}




\begin{tabular}{|c|c|c|c|c|c|c|c|c|c|c|}
\hline Quality of your relationships with your Partner & 9 & 9 & 0.907 & 1 & 2 & 4 & 0 & 0 & 2 & 0.069 \\
\hline A lot better & 22 & 25 & & 3 & 10 & 1 & 7 & 1 & 3 & \\
\hline A little better & 76 & 88 & & 1 & 24 & 9 & 17 & 9 & 28 & \\
\hline About the same & 27 & 24 & & 0 & 6 & 2 & 8 & 0 & 8 & \\
\hline A little worse & 7 & 10 & & 0 & 3 & 1 & 2 & 0 & 4 & \\
\hline \multicolumn{11}{|l|}{ A lot worse } \\
\hline Drugs increases after COVID-19 & 162 & 157 & 0.019 & 9 & 45 & 16 & 34 & 10 & 43 & 0.269 \\
\hline No drugs & 38 & 37 & & 3 & 14 & 8 & 5 & 1 & 6 & \\
\hline Analgesics and NSAIDS & 10 & 7 & & 0 & 3 & 1 & 2 & 0 & 1 & \\
\hline OTC flu medications & 1 & 6 & & 0 & 2 & 0 & 2 & 0 & 2 & \\
\hline Hypnotics & 2 & 5 & & 0 & 4 & 0 & 1 & 0 & 0 & \\
\hline Antibiotics & 9 & 5 & & 1 & 2 & 0 & 1 & 0 & 1 & \\
\hline Other & 1 & 12 & & 0 & 5 & 2 & 2 & 0 & 3 & \\
\hline 2 drugs & 0 & 1 & & 0 & 1 & 0 & 0 & 0 & 0 & \\
\hline \multicolumn{11}{|l|}{3 drugs or more } \\
\hline Drugs increases for your family & 167 & 194 & 0.362 & 11 & 63 & 23 & 41 & 10 & 46 & 0.999 \\
\hline No drugs & 30 & 26 & & 1 & 9 & 4 & 4 & 1 & 7 & \\
\hline Analgesics and NSAIDS & 8 & 5 & & 0 & 2 & 1 & 2 & 0 & 0 & \\
\hline OTC flu medications & 1 & 2 & & 0 & 1 & 0 & 1 & 0 & 0 & \\
\hline Hypnotics & 1 & 0 & & 0 & 0 & 0 & 0 & 0 & 0 & \\
\hline Antibiotics & 5 & 4 & & 1 & 1 & 0 & 0 & 0 & 2 & \\
\hline Other & 5 & 1 & & 0 & 1 & 0 & 0 & 0 & 0 & \\
\hline 2 drugs & 1 & 0 & & 0 & 0 & 0 & 0 & 0 & 0 & \\
\hline 3 drugs or more & & & & & & & & & & \\
\hline
\end{tabular}


Table 3: K10 scores, days unable to work, social support and PTSD in different countries.

\begin{tabular}{|c|c|c|c|c|c|c|c|c|c|c|}
\hline Characteristic & $\begin{array}{c}\text { Syria } \\
\text { Mean } \\
\text { (SD) }\end{array}$ & $\begin{array}{l}\text { Outside Syria } \\
\text { Mean } \\
\text { (SD) }\end{array}$ & $\begin{array}{c}P \\
\text { value }\end{array}$ & $\begin{array}{c}\text { Nearby } \\
\text { country } \\
\text { Mean } \\
\text { (SD) }\end{array}$ & $\begin{array}{c}\text { Canada } \\
\text { Mean } \\
\text { (SD) }\end{array}$ & $\begin{array}{c}\text { Egypt } \\
\text { Mean } \\
\text { (SD) }\end{array}$ & $\begin{array}{c}\text { UAE } \\
\text { Mean } \\
\text { (SD) }\end{array}$ & $\begin{array}{c}\text { Russia } \\
\text { Mean } \\
\text { (SD) }\end{array}$ & $\begin{array}{c}\text { Germany } \\
\text { Mean } \\
\text { (SD) }\end{array}$ & $\begin{array}{c}P \\
\text { value }\end{array}$ \\
\hline Arousal & $\begin{array}{c}1.55 \\
(1.427)\end{array}$ & $\begin{array}{c}1.79 \\
(1.563)\end{array}$ & 0.089 & $\begin{array}{c}1.80 \\
(1.560)\end{array}$ & $\begin{array}{c}1.46 \\
(1.266)\end{array}$ & $\begin{array}{c}1.69 \\
(1.569)\end{array}$ & $\begin{array}{c}1.96 \\
(1.641)\end{array}$ & $\begin{array}{c}2.73 \\
(1.272)\end{array}$ & $\begin{array}{c}1.56 \\
(1.586)\end{array}$ & 0.131 \\
\hline Avoidance & $\begin{array}{c}1.82 \\
(1.726)\end{array}$ & $\begin{array}{l}2.17 \\
(1.889)\end{array}$ & 0.035 & $\begin{array}{l}2.59 \\
(1.968)\end{array}$ & $\begin{array}{c}1.69 \\
(1.974)\end{array}$ & $\begin{array}{c}2.04 \\
(1.605)\end{array}$ & $\begin{array}{l}2.17 \\
(1.872)\end{array}$ & $\begin{array}{l}2.00 \\
(2.145)\end{array}$ & $\begin{array}{c}1.82 \\
(1.820)\end{array}$ & 0.067 \\
\hline Re-experience & $\begin{array}{c}0.93 \\
(1.284)\end{array}$ & $\begin{array}{c}1.21 \\
(1.600)\end{array}$ & 0.042 & $\begin{array}{c}1.38 \\
(1.686)\end{array}$ & $\begin{array}{c}1.00 \\
(1.206)\end{array}$ & $\begin{array}{c}0.85 \\
(1.287)\end{array}$ & $\begin{array}{c}1.27 \\
(1.724)\end{array}$ & $\begin{array}{c}1.18 \\
(1.471)\end{array}$ & $\begin{array}{c}1.15 \\
(1.638)\end{array}$ & 0.307 \\
\hline Total SPTSS & $\begin{array}{c}4.30 \\
(3.735)\end{array}$ & $\begin{array}{c}5.07 \\
(4.422)\end{array}$ & 0.045 & $\begin{array}{c}5.71 \\
(4.630)\end{array}$ & $\begin{array}{c}4.08 \\
(3.796)\end{array}$ & $\begin{array}{c}4.48 \\
(3.435)\end{array}$ & $\begin{array}{l}5.27 \\
(4.698)\end{array}$ & $\begin{array}{c}5.91 \\
(4.571)\end{array}$ & $\begin{array}{c}4.39 \\
(4.422)\end{array}$ & 0.158 \\
\hline Friends support & $\begin{array}{l}15.620 \\
(7.5494)\end{array}$ & $\begin{array}{l}15.232 \\
(7.7590)\end{array}$ & 0.590 & $\begin{array}{l}15.372 \\
(8.1975)\end{array}$ & $\begin{array}{l}14.269 \\
(8.9550)\end{array}$ & $\begin{array}{l}15.115 \\
(6.4750)\end{array}$ & $\begin{array}{l}16.848 \\
(8.0415)\end{array}$ & $\begin{array}{c}7.727 \\
(4.5131) \\
\end{array}$ & $\begin{array}{l}15.481 \\
(7.0557)\end{array}$ & 0.038 \\
\hline Family support & $\begin{array}{l}19.097 \\
(6.9193)\end{array}$ & $\begin{array}{l}19.613 \\
(6.8274)\end{array}$ & 0.423 & $\begin{array}{l}18.633 \\
(6.9157)\end{array}$ & $\begin{array}{l}19.500 \\
(9.0692)\end{array}$ & $\begin{array}{l}19.058 \\
(6.5793)\end{array}$ & $\begin{array}{l}20.924 \\
(6.6533)\end{array}$ & $\begin{array}{l}20.500 \\
(7.5299)\end{array}$ & $\begin{array}{l}19.972 \\
(6.2935)\end{array}$ & 0.632 \\
\hline Significant other support & $\begin{array}{l}19.273 \\
(7.6526)\end{array}$ & $\begin{array}{l}20.226 \\
(7.3404)\end{array}$ & 0.174 & $\begin{array}{l}19.880 \\
(6.8556)\end{array}$ & $\begin{array}{l}19.923 \\
(8.4307)\end{array}$ & $\begin{array}{l}19.111 \\
(8.1090)\end{array}$ & $\begin{array}{l}21.340 \\
(7.4324)\end{array}$ & $\begin{array}{l}18.864 \\
(7.7495)\end{array}$ & $\begin{array}{l}20.636 \\
(7.3500)\end{array}$ & 0.653 \\
\hline Total social support & $\begin{array}{c}53.85 \\
(18.307)\end{array}$ & $\begin{array}{c}54.55 \\
(18.263)\end{array}$ & 0.686 & $\begin{array}{c}53.68 \\
(17.675)\end{array}$ & $\begin{array}{c}53.69 \\
(21.092)\end{array}$ & $\begin{array}{c}52.02 \\
(19.812)\end{array}$ & $\begin{array}{c}58.31 \\
(19.702)\end{array}$ & $\begin{array}{c}47.09 \\
(15.152)\end{array}$ & $\begin{array}{c}55.45 \\
(16.854)\end{array}$ & 0.567 \\
\hline Total K 10 support & $\begin{array}{l}22.5633 \\
(8.74049)\end{array}$ & $\begin{array}{l}23.4474 \\
(9.63162)\end{array}$ & 0.305 & $\begin{array}{l}23.8108 \\
(9.26131)\end{array}$ & $\begin{array}{c}20.1538 \\
(10.91517)\end{array}$ & $\begin{array}{c}24.6071 \\
(10.71288)\end{array}$ & $\begin{array}{l}24.4681 \\
(8.74481)\end{array}$ & $\begin{array}{l}20.3636 \\
(7.24255)\end{array}$ & $\begin{array}{c}22.8909 \\
(10.42375)\end{array}$ & 0.508 \\
\hline $\begin{array}{l}\text { Days unable to work in the past } 4 \\
\text { weeks }\end{array}$ & $\begin{array}{c}7.81 \\
(11.050)\end{array}$ & $\begin{array}{c}179220.15 \\
(2444117.919)\end{array}$ & 0.326 & $\begin{array}{c}584802.67 \\
(4415106.822)\end{array}$ & $\begin{array}{c}5.55 \\
(9.048)\end{array}$ & $\begin{array}{c}5.41 \\
(6.681)\end{array}$ & $\begin{array}{c}14.82 \\
(58.913)\end{array}$ & $\begin{array}{c}7.44 \\
(7.502)\end{array}$ & $\begin{array}{c}7.88 \\
(7.860)\end{array}$ & 0.493 \\
\hline
\end{tabular}

Figures 


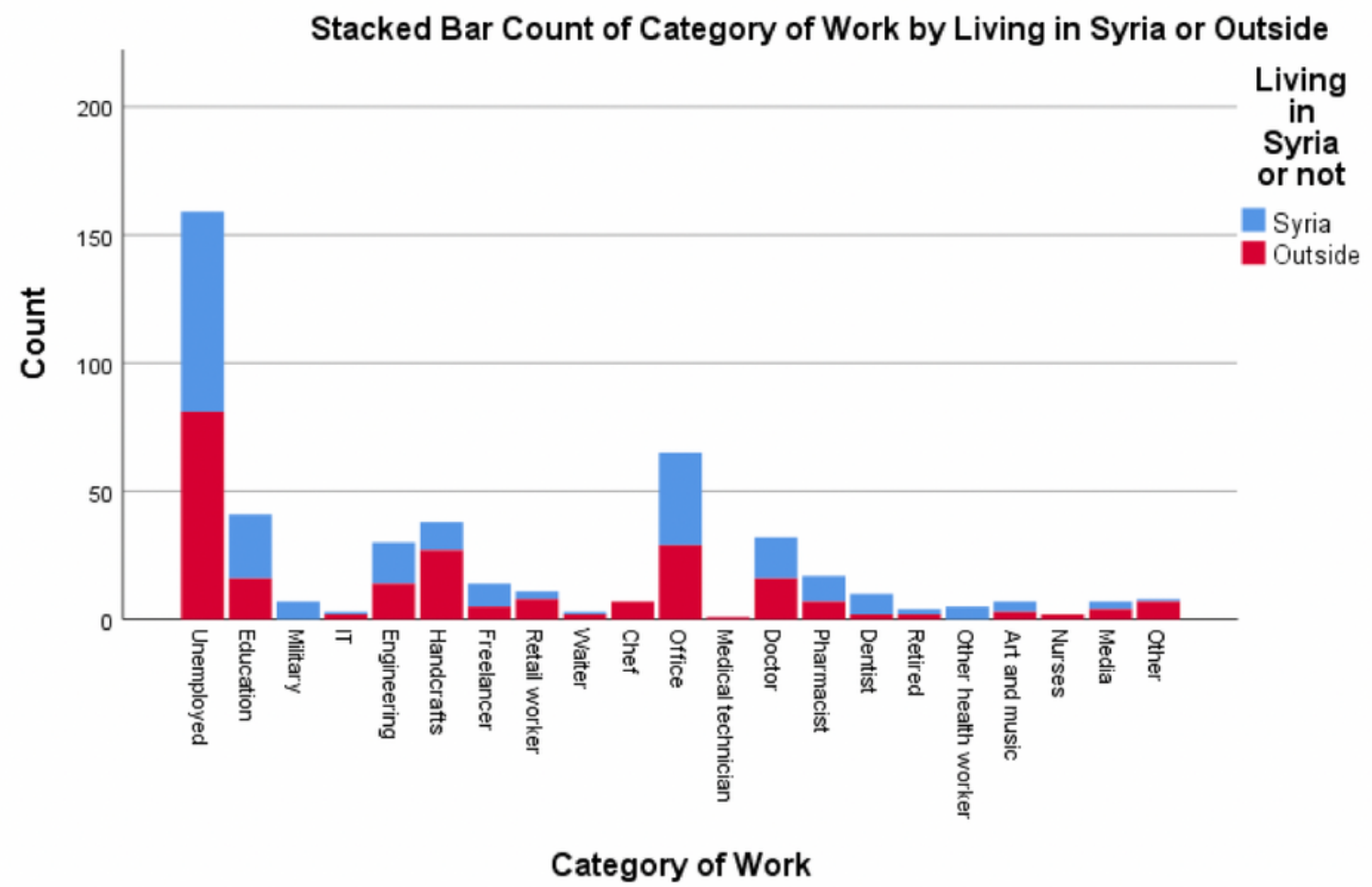

Figure 1

demonstrating participants' work category according to living in Syria or not 
Simple Bar Mean of Total SPTSS Score by Work Category by Inside Syria and Outside by Gender

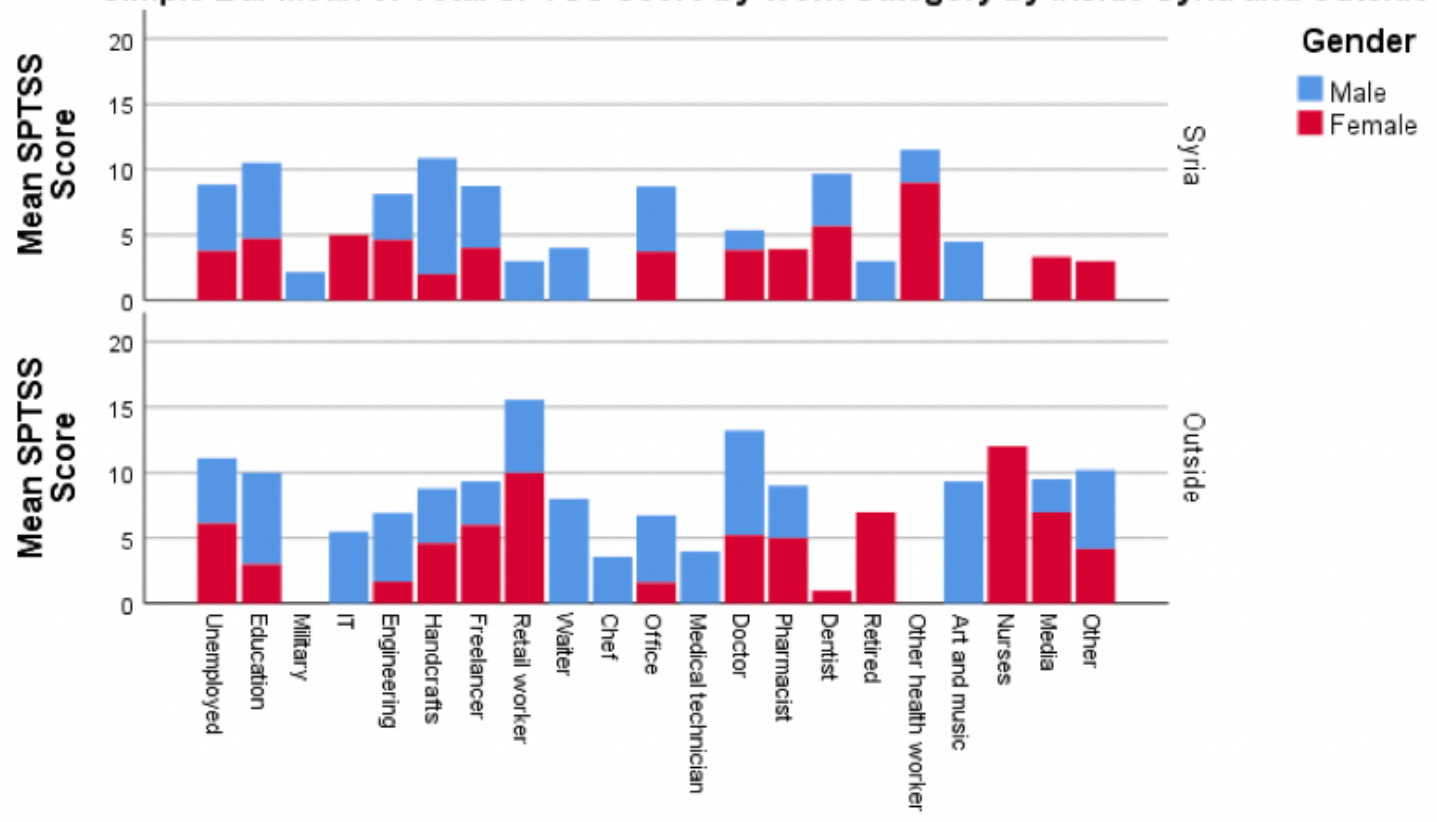

Work Category

Figure 2

demonstrating participants' work category according to SPTSS scores, living in Syria or not, and gender 